Historic, Archive Document

Do not assume content reflects current scientific knowledge, policies, or practices. 



\section{THE DOLLAR BULLETIN}

maRech 1915

\section{THE VAN DUSEN NURSERIES W. L. McKAY, Prop., Geneva, N. Y.}
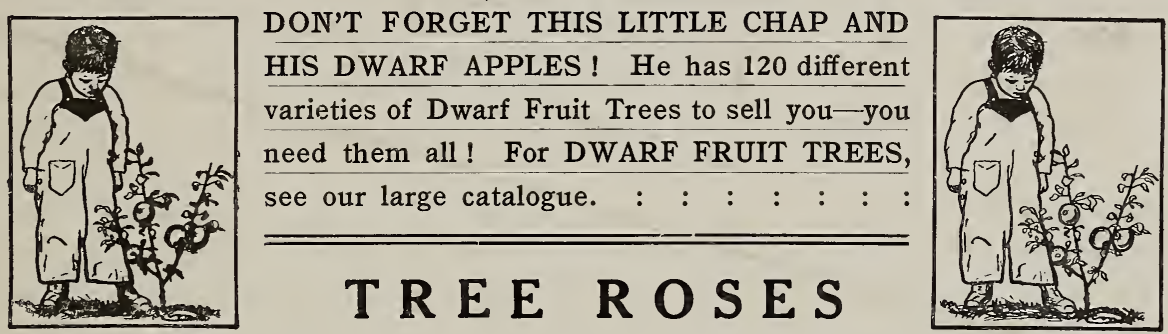

There is no more beautiful plant than a rose in bloom, and when the plant happens to be a tree rose, four or five feet tall and loaded with blossoms, it is doubly beautiful. We offer three varieties, probably as choice representatives of the three colors they represent, as any three roses we could select.

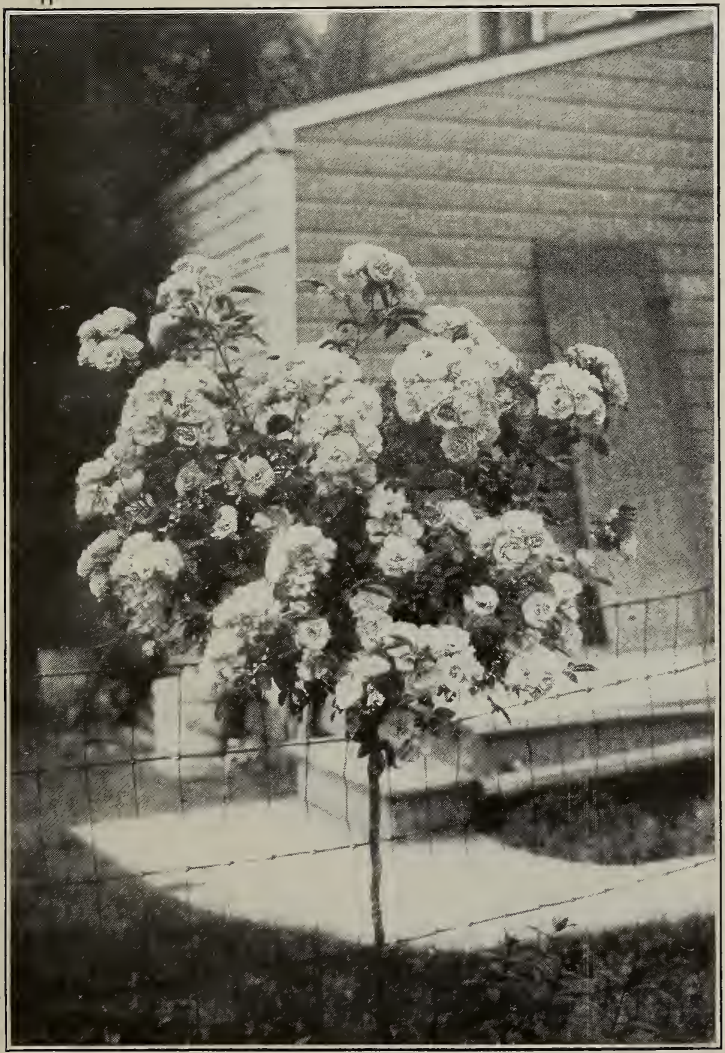

For the white variety we have the Frau Karl Druschki or "Snow Queen." I would place the blooms of this variety at the very head of all white roses for beauty; they are extremely large, but their slight tendency to be less double than most varieties relieves the bloom from anything like coarseness. A most beautiful bud; when fully opened is nearly as large as a Camelia, which it somewhat resembles. Blooms at intervals all summer.

For a red variety we have chosen the Gruss an Teplitz, which we consider perhaps the best adapted of all for lawn decoration, as the Teplitz blooms literally from June till late fall. It has a most wonderful color-call it red if you please, but better still, call it "Gruss an Teplitz" color; for there is no other color like it and it baffles all attempts at description. It has long, pointed buds like the Frau Karl, but not so large.

For a pink variety we offer Mrs. John Laing which we regard as one of the best of this color. It is a free bloomer, continuing through the summer.

Prices, $\$ 1.00$ each, $\$ 9.00$ per dozen. One of each of above three kinds, $\$ 2.25$.

Should we sell out of any of these varieTREE ROSE ties, we will send the nearest in color possible unless you indicate otherwise. 


\section{DOLLAR BUNDLES}

\section{All sales cash with order}

In every block of mature apple and pear trees there are the four grades of first-class trees as shown in the accompanying cut- " $\mathrm{A}$ " which is the cream of the block, is the grade that constitutes our "Extra" size trees listed in our catalogue. If you are planting only a few trees of different varieties, this is the grade that will give you the best satisfactionyou want a good, big handsome tree, and here you get it. For this reason it is only in this grade of trees that we list them at single rates.

This leaves the sizes marked "B," "C" and "D." While the extra size takes the majority of a good block, there are too many in these perfectly good smaller sizes to throw away. Therefore, they go into our "Dollar Bulletin" and are offered in the different sizes as listed on pages 3 and 4 , by the bundle.

This enables us to maintain the very highest grading for our "Extra" size and at the same time provides an outlet for these smaller sizes at prices which enables the orchard planter to buy trees at half price or less, which, planted in orchard, will serve his purpose and make very little difference in the time of coming into bearing. Not that we advise these in preference to the "Extras" for orchard planting-there is no better stock than our extra size for any purpose, but for the man who wants to plant say a thousand trees and can only afford to buy 500 of the extra size this year, it will pay him instead to buy the thousand of the lighter grade at the cost of the 500 extras and have them all started together.

So this year we are putting our trees up in "dollar" bundles, which are offered under the following conditions:

(1) All sales from this Bulletin are under the same guaranty and provisions for substituting as stated on the inside of the front cover of our large catalogue which has been sent you. Be sure, therefore, to state whether, if out of either the size or the variety you order, you wish us to substitute either in size or variety. If you wish no change whatever in your order and we cannot fill it as specified, your money will be returned. I would suggest first a substitution of sizes of the same variety, and then, if entirely out of that variety, a change to some other as near like it as possible.

(2) At these prices, bundles will not be broken-please do not ask it as it will only cause delay, and, if insisted on, the return of your money; except that if your order is for one hundred trees of one kind of fruit, we will then divide your order as desired.

(3) Orders will be filled only when accompanied by the cash-either money order, draft, or your own personal check.

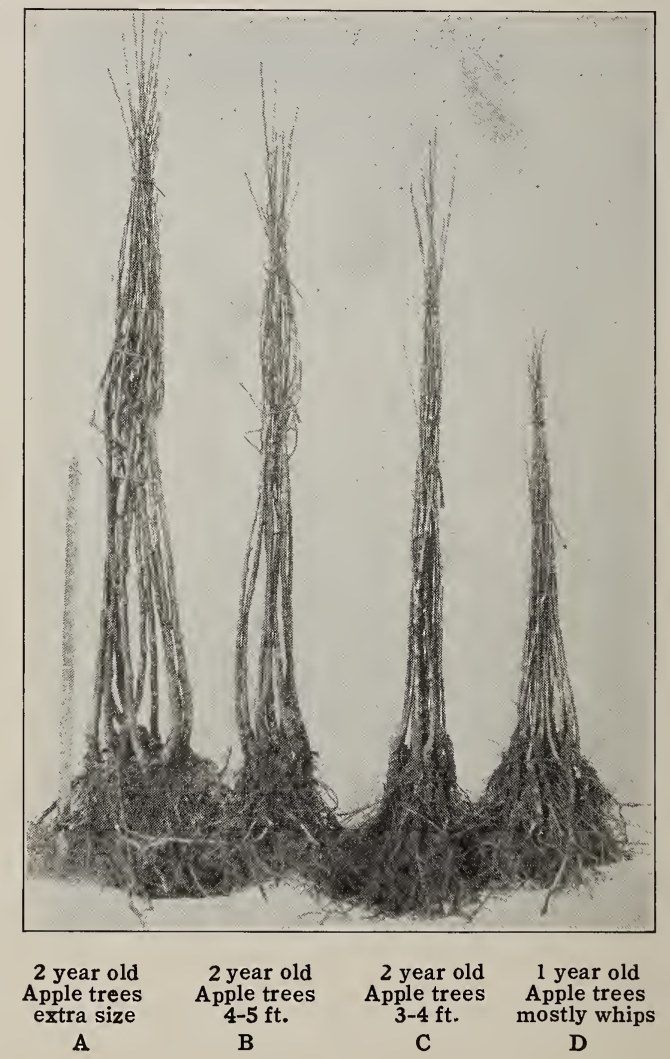




\section{STANDARD APPLE TREES}

Grade "B," 4-5 feet, $\$ 1.00$ per bundle of 10 trees

Many of these trees might well go into Grade "A," except that the "A" trees must be kept to a grade beyond criticism, and the very best that money will buy in any market. These Grade "B" trees are a great bargain for the orchard planter at the price offered.

40 Bailey Sweet

1000 Baldwin

60 Ben Davis

130 Black Ben Davis

30 Boiken

40 Constantine

120 Duchess

20 Fameuse

10 Hendrick Sweet

30 Hubbardston

70 Jonathan
90 King

10 Lady Sweet

700 McIntosh

300 Northern Spy

50 Pewaukee

40 Pound Sweet

50 Red Astrachan

400 R. I. Greening

70 Rome Beauty

70 Spitzenburg

300 Stark
300 Stayman Winesap
200 Scarlet Beauty
100 Stearns
30 Tolman Sweet
100 Twenty Ounce
20 Wagener
200 Wealthy
150 Winter Banana
150 Wolf River
50 Yellow Transparent

\section{Grade "C," 3-4 feet, $\$ 1.00$ per bundle of 15 trees}

These are fine little trees, well rooted, branched, and as strictly first-class as any-the only difference is one of size.

40 Bailey Sweet

800 Baldwin

50 Ben Davis

50 Black Ben Davis

30 Boiken

20 Constantine

150 Duchess

50 Fameuse

20 Grimes' Golden

20 Hendrick Sweet

50 Hubbardston
20 Jonathan

60 King

500 McIntosh

200 Northern Spy

10 Pound Sweet

70 Red Astrachan

300 R. I. Greening

70 Rome Beauty

70 Seek-no-Further

100 Spitzenburg

300 Stark
300 Stayman Winesap

70 Scarlet Beauty

170 Stearns

30 Tolman Sweet

100 Twenty Ounce

20 Wagener

150 Wealthy

60 Winter Banana

50 Wolf River

20 Yellow Belleflower

70 Yellow Transparent

Grade "D," mostly one year old whips, about 3 feet, $\$ 1.00$ per bundle of 15 trees
20 Bailey. Sweet
270 Baldwin
60 Duchess
20 King
70 Northern Spy

\author{
10 Red Astrachan \\ 110 R. I. Greening \\ 30 Spitz \\ 10 Stark \\ 40 Stayman Winesap
}

20 Stearns

10 Tolman Sweet

90 Wealthy

10 Wolf River

30 Yellow Transparent

\section{STANDARD PEAR TREES}

Grade "B," 4-5 feet, $\$ 1.00$ per bundle of 6 trees, except Bosc

18 Anjou

878 Bartlett
129 Bosc (bundle, 2 trees)

165 Clapp
12 Flemish

18 Kieffer

Grade "C," 3-4 feet, \$1.00 per bundle of 9 trees, except Bosc

9 Anjou

1125 Bartlett

100 Bosc (bundle, 3 trees)
214 Clapp

18 Kieffer
63 Lawrence

189 Seckel

Grade "D," mostly 1 year whips, about 3 feet, $\$ 1.00$ per bundle of 9 trees

200 Bartlett

See our "BOSC SPECIAL" offer, Catalogue page $14 ; 40$ c each by mail, $\$ 25.00$ per 100 by express. 


\section{STANDARD PLUM TREES}

30 Bradshaw 150 Burbank
122 Shropshire Damson
GRADE “B," 4-6 feet, $\$ 1.00$ per bundle of 6 trees

172 German Prune

smooth as we require for our best grade. They are an unusually good bargain.

\section{STANDARD CHERRY TREES}

180 English Morello

Grade "B," about $31 / 2-5$ feet, $\$ 1.00$ per bundle of 4 trees

600 Montmorency

300 Montmorency

Grade "C," about 3 feet, $\$ 1.00$ per bundle of 6 trees

Grade "D," one year old, 2-3 feet, extra nice stock, $\$ 1.00$ per bundle of 6 trees 460 Montmorency

\section{STANDARD PEACH TREES}

In peach trees we have but few varieties to offer other than at our catalogue list rates, but we offer a few to make the bundle offer complete. The size marked " $\mathrm{A}$ " in the cut is our best, extra size trees, and we offer below a few kinds in sizes "B" and "C".

500 Carman

500 Champion
Grade "B," about 3-4 feet, $\$ 1.00$ per bundle of 10 trees

300 Crawford's Early

100 Crawford's Late
500 Elberta

100 Niagara

Grade "C," 2-3 feet, $\$ 1.00$ per bundle of 15 trees

100 Belle of Georgia 600 Champion 100 Niagara 600 Carman 500 Elberta

100 Stevens

\section{A FEW DWARF BARGAINS}

\section{DWARF APPLES FOR $\$ 1.00$}

Your choice of these four kinds

McIntosh

Baldwin
Northern Spy

R. I. Greening

We want you to become acquainted with dwarf trees and get first hand experience with them for yourself. We want to GET THEM INTO YOUR HANDS, with instructions how to manage them, so you may learn for yourself the possibilities of dwarf fruit trees.

\section{DWARF \\ McINTOSH COLLECTION}

1 Dwf. McIntosh Apple, $\$ .501$ Dwf. Willet, $\$ .50$

1 Dwf. Seckel Pear

1 Dwf. Damson Plum

1 Dwf. Montmorency

Cherry

1 Dwf. Sand Cherry

1 Dwf. Elberta Peach

List Price

COLLECTION PRICE $\$ 2.00$

\section{DWARF WILLET PEACH COLLECTION} ford

1 Dwf. Elberta .30

.601 Dwf. Carman .30

.251 Dwf. Fitzgerald .30

.301 Dwf. Niagara .30

$\overline{\$ 2.65}$ List Price $\overline{\$ 2.00}$ COLOR COLLECTION OF DWARF PEACHES

Champion, white without blush.

Crimson Beauty, solid dark crimson.

Fitzgerald, golden yellow.

Niagara, orange red on yellow.

Belle of Georgia, white with pink blush.

McKay's Late, pale yellow.

List price....................... \$2.00

COLLECTION PRICE ............. $\$ 1.50$ In this collection, if we are 'later sold out of a variety, we will substitute a suitable vasiety correctly labeled.

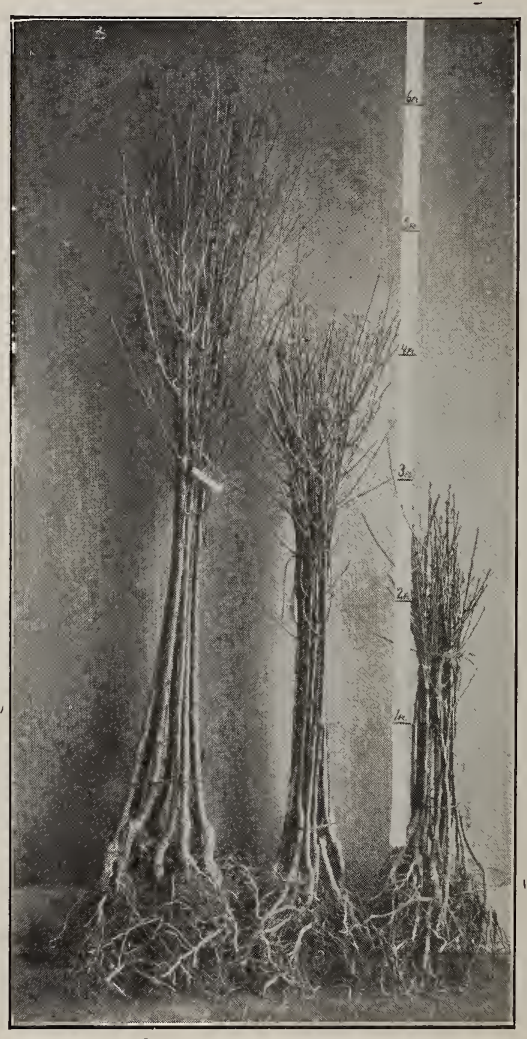

A

B

C

Our Three Sizes of Peach Trees 


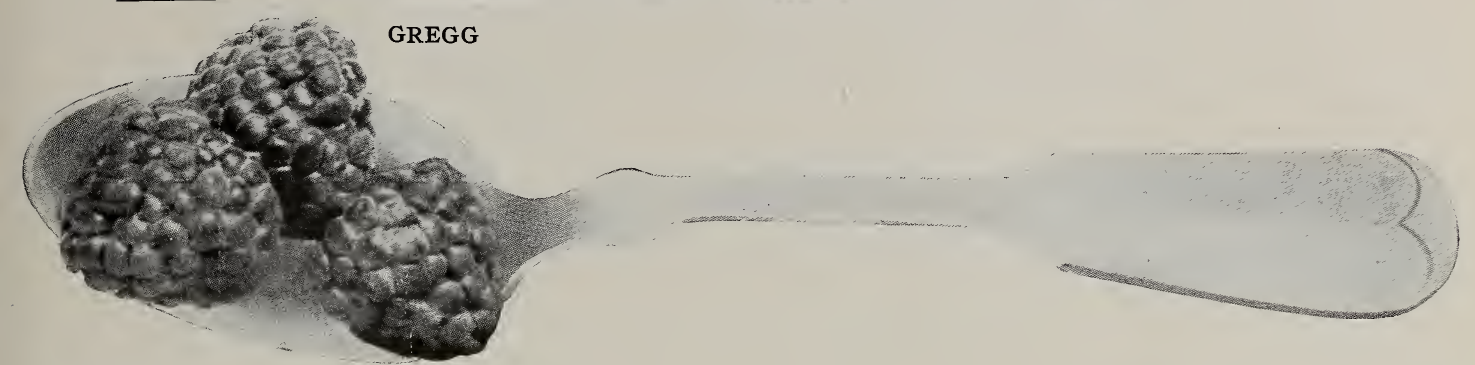

\section{TWO SMALL FRUIT COLLECTIONS "JUNIOR" AND "SENIOR"}

Our orders this spring are running mostly to trees-we are offering these two collections as an inducement for our customers to acquire the small fruit habit, and incidentally, we add a dwarf tree or two-just enough to give you a taste for them! Pinch them back as directed on page 7 of the catalogue, and make them give you fruit in 1916 .

In ordering these collections, do not list them on the order-just say "Junior Collection" or "Senior Collection."

\section{JUNIOR COLLECTION- $\$ 3.00$}

The Choicest, high priced varieties are printed in black face type

12 Strawberries, Everbearing

6 St. Regis Raspberries, Red, Everbearing

6 Cuthbert, Raspberries Red

6 Columbian Raspberries, Purple

6 Gregg, Raspberries, Black

1 Cherry Currant, Red

1 Fay Currant, Red

1 White Grape Currant

1 Dwarf Baldwin Apple Tree
6 Ancient Briton Blackberries

6 Snyder Blackberries

3 Rhubarb, McKay's Mammoth

1 Agawam Grape, Red

1 Concord Grape, Black

1 Moore Early Grape, Black

1 Niagara Grape, White

3 Houghton Gooseberries, Red

25 McKay's Giant Asparagus

SENIOR COLLECTION- $\$ 5.00$

The choicest, high priced varieties are printed in black face type

25 Strawberries, Everbearing

6 St. Regis Raspberries, Red, Everbearing

6 June Raspberries, Red

6 Herbert Raspberries, Red

6 Golden Queen Raspberries, Yellow

6 Royal Purple Raspberries, Purple

6 Plum Farmer Raspberries, Black

6 Rhubarb, McKay's Mammoth

50 Asparagus, McKay's Giant

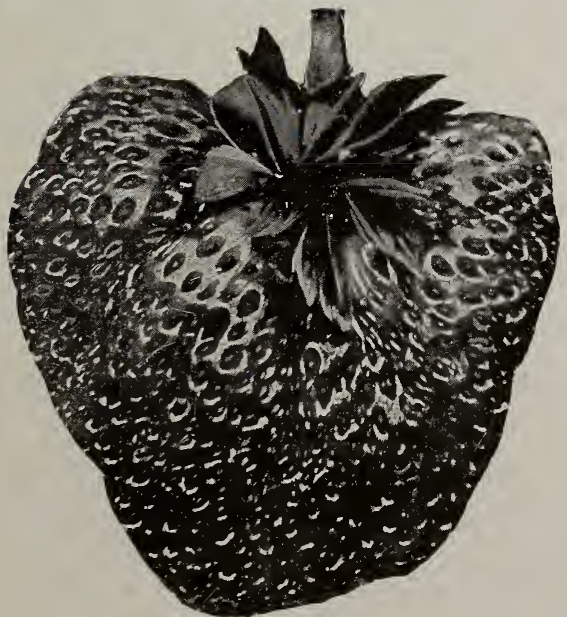

1 Dwarf Baldwin Apple Tree

1 Dwarf Northern Spy Apple Tree

1 Dwarf Elberta Peach Tree

6 Blowers Blackberries

6 Taylor Blackberries

6 Mersereau Blackberries

1 Concord Grape, Black

1 Delaware Grape, Red

1 Diamond Grape, White

1 Worden Grape, Black

6 Houghton Gooseberries, Red

1 Currant, Black Champion

3 Cherry Currants, Red

1 Perfection Currant, Red

1 White Grape Currant

\section{Everbearing Strawberries}

We think very highly of some varieties of the Everbearing Strawberries. See our catalogue page 44 for proper method of handling them. We would like to get them into the hands of as many of our customers as possible. To introduce it more widely we will mail you 12 Everbearing Strawberry plants and 6 of any variety of Raspberry you may select, for $\$ 1.00-P O S T$ PAID. 


\section{Lakeside Collection}

\section{$\$ 1.75$ POST PAID}

These Twelve Grape Vines, POST PAID for only $\$ 1.75$. See Catalogue page 40 for full description of varieties.

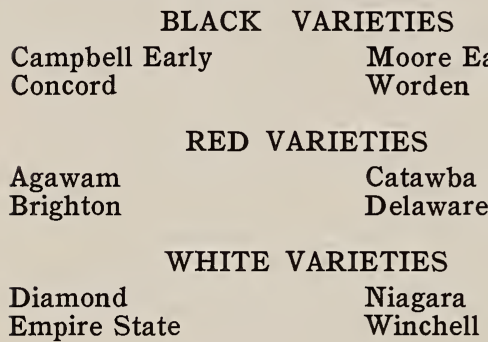

\section{Arbor Collection}

\section{$\$ 1.10$ POST PAID}

These Grapes are shown in colors on the outside of back cover of catalogue, $\$ 1.10$ POST PAID.

Catawba, Red

Campbell, Black

Delaware, Red
Niagara, White

Moore Early, Black

Winchell, White

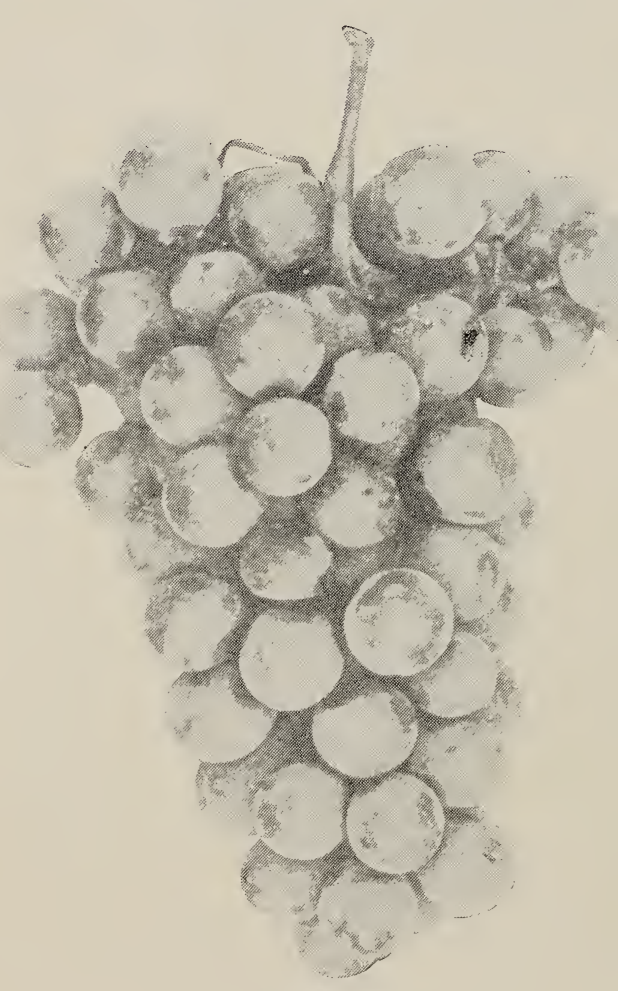

DIAMOND

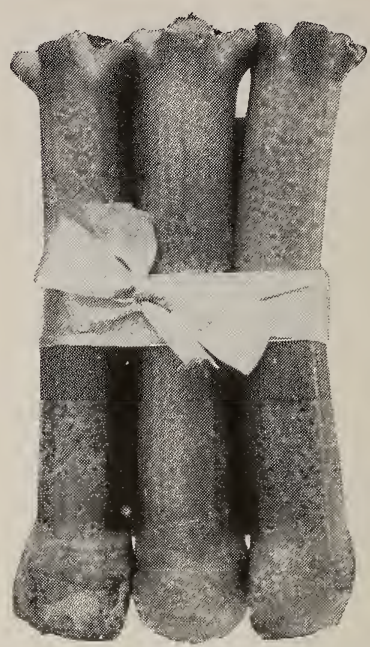

MCKAY'S MAMMOTH RHUBARB

$\mathbf{R} \mathbf{h} \mathbf{u} \mathbf{b} \mathbf{a} \mathbf{r} \mathbf{b}$

POST PAID

McKAY'S MAMMOTH-A very strong growing, tender, delicious variety. Every garden should have a row of Rhubarb.

25 c each, $\$ 2.50$ per doz.

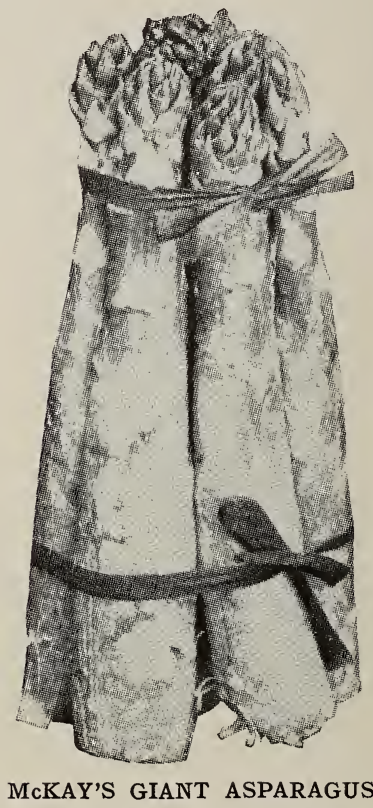

Asparagus

POST PAID

McKAY'S GIANT-A new variety, which has proven to be a most delicious variety and a great cropper. $50 \mathrm{c}$ per $25, \$ 1.25$ per 100. 


\section{THE VAN DUSEN NURSERIES, Geneva, N. Y.}

\section{PLEASE USE THIS ORDER SHEET. ALL STOCK F. O. B. GENEVA.}

Ordered by

Post Office.

County

State.

These three lines
need be filled in
ONLY when the
party sending in
ord er wishes the
shipment made to
Some o T H E R
PERSON.

R. R. Station.

Name of R. R.

Express Office.

Express Co.

Enclosed find \$.

In form of.

Small orders that go in a bale or very small box, we ship by express; orders requiring a tree box, by freight, unless you direct olherwise, or unless too late to safely warrant freight shipment.

\section{LIST YOUR ORDER ON REVERSE SIDE}

Order Rec'd.

Ack.

Agg

Tagged.

Order Shipped.

Notified

Do not worry if stock does not always come as soon as you may expect. Remember it is to our advantage as much as yours to have the trees reach you in time for safe planting.

We will send our Catalogue Free to people whom you think it will interest.

NAMES

ADDRESSES 


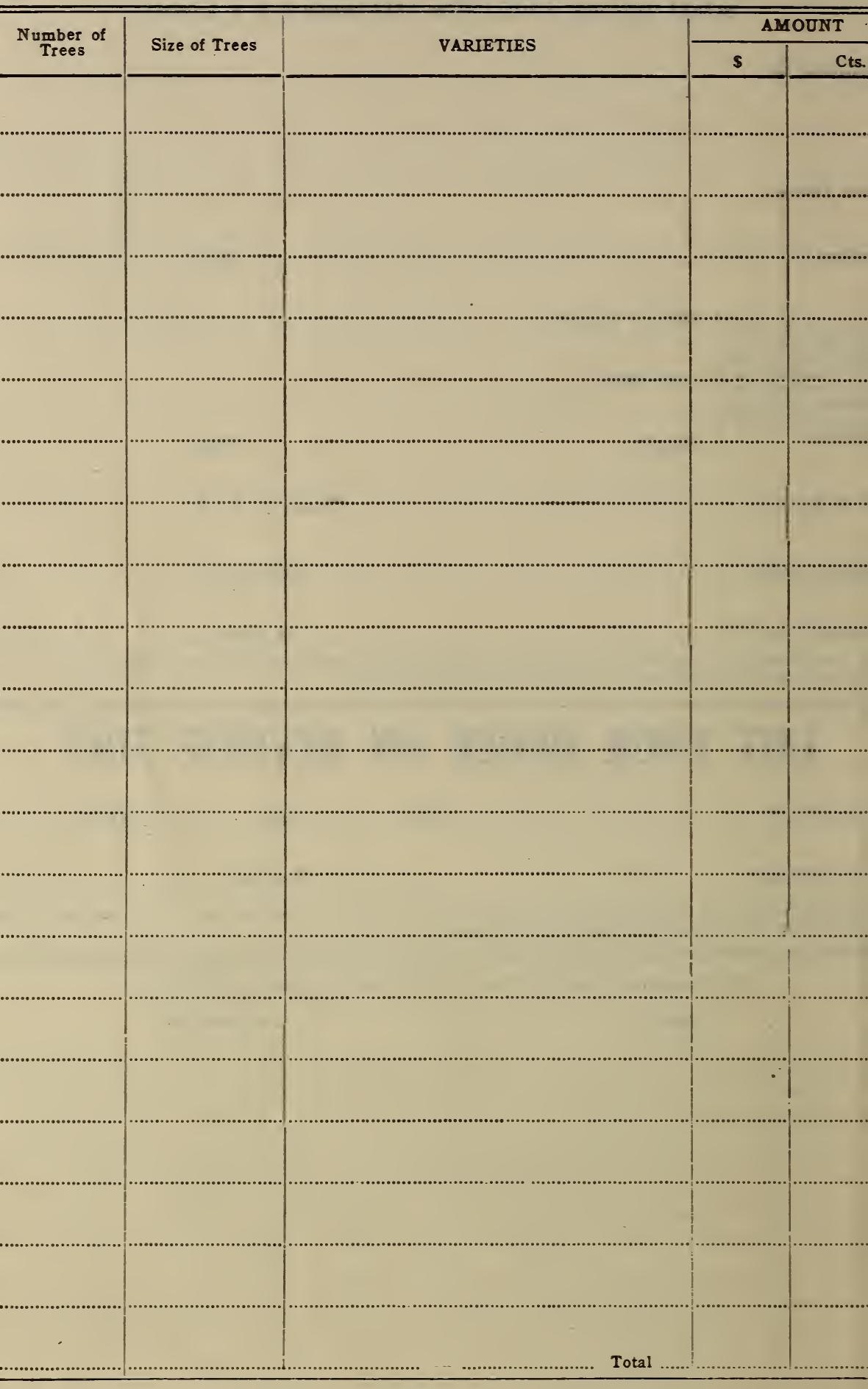




\section{SHADE TREE COLLECTION, 50c. POST PAID}

Shade trees cost more than any other class of nursery stock, owing to their size and the larger expense of packing and transportation.

Here are some little fellows, however, for almost nothing. They are about a foot in height, some probably running close to two feet.
1 Russian Mulberry
1 Catalpa Speciosa
1 Norway Maple
1 Black Walnut

\section{European White Birch}

These little trees, in from one to three years, according to variety, will grow to a size which would cost you about $\$ 5.00$, including expressage. They are listed in order of the rapidity of their growth.

\section{CAROLINA POPLAR, 2-3 ft., only 50c, POST PAID}

The same trees, not less than $50, \$ 5.00$ per 100 by express

\section{BEST FLOWERING SHRUBS FOR 50c. Post Paid}

These are a great bargain. They will be full grown shrubs the size we usually ship in a year or two. About 6 to 12 inches. They will be selected from such shrubs as Barberries, Forsythias, Honeysuckles, Fringes, Lilacs, Spireas, Syringas, Weigelas, etc., entirely our selection of varieties.

The JAPANESE BARBERRY is without doubt the most valuable ornamental shrub that has ever been introduced. There is no other so perfectly adapted to the three great uses of shrubs in landscape architecture-for massing, for hedging, and for individual, specimen plants. It seems to me to stand first of all shrubs for each of these three purposes.

If the residences on an entire street used no other shrub than this one, it would not impress one as monotonous or unusual - the lack of other shrubs would hardly be noticed; what other shrub is there that could stand such a test?

Having no conspicuous bloom, there is perhaps no particular time when it is at its bestit is always at its best! It is distinctly a shrub of the seasons-a different shrub for each season; the new spring foliage is a light, almost grayish green, changing to a strong, dark, glossy green for its summer foliage; with the coming of fall it again changes to all the different shades and combinations of reds, yellows and greens imaginable, and during winter it remains a mass of bright red berries.

In the engraving the Barberry is shown in the circling hedge at the left.

The Japanese Barberry is included in our above offer of six shrubs by mail. Strong plants about 2 feet high, 25c. For hedging, in lots of 50 plants or over, $\$ 15.00$ per 100.

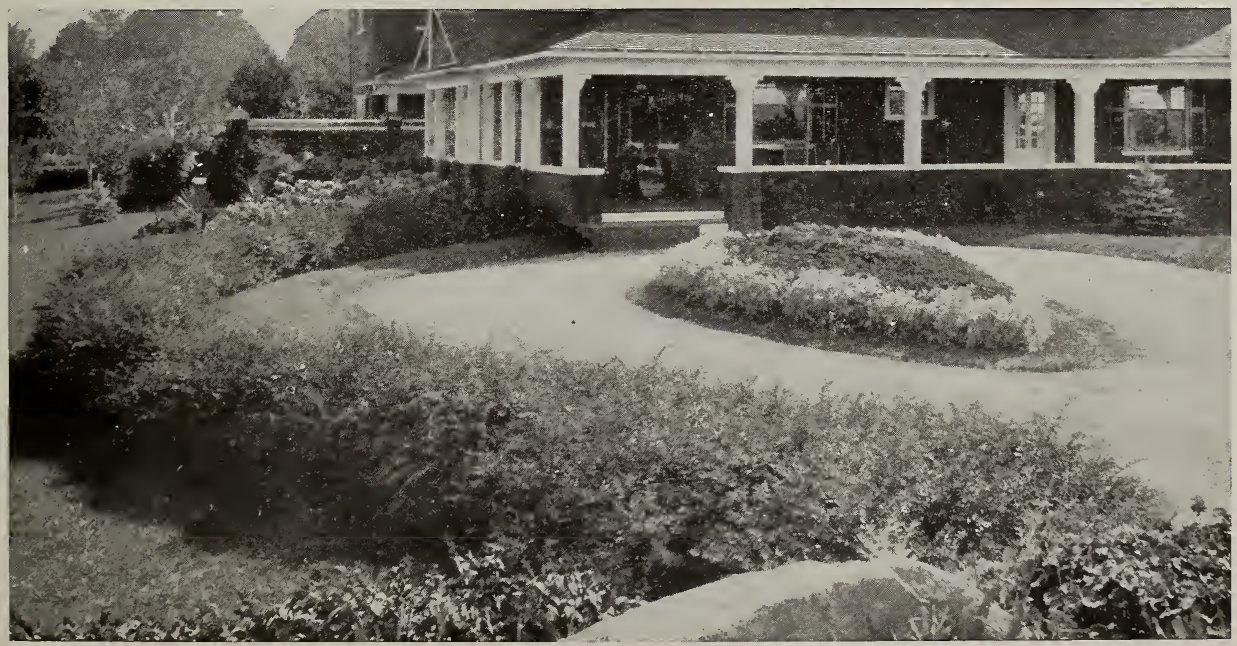

JAPANESE BARBERRY HEDGE. 


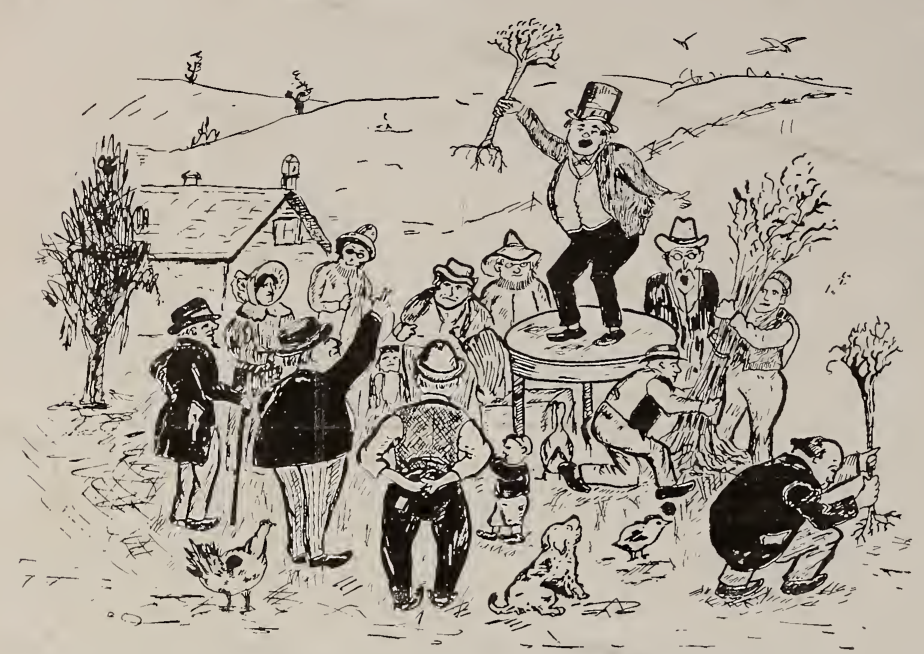

\section{You Guessed Just Right ! It's an Auction!!}

In digging trees for our spring sales, we have to "guess" at the number of each variety likely to be wanted. If we make a close guess, we dignify it by calling it an "estimate," but all the same, in plain English, its just "guessing."

There are many kinds of which we are short and shall have to dig still more, but from sales to date it would seem that we are long on varieties listed below, and to about the number stated-which is also "guessing" some more! At any rate the number of each variety entered below will be sold to the highest bidders, till they are all sold.

(1) When the number offered of each variety is sold all further bids will be declined.

(2) No bids will be accepted for a greater number than listed.

(3) No cash need accompany bids, but the amount bid becomes due immediately on receipt of notice of the acceptance of a bid.

(4) If at any time the number still unsold is taken by two or more bids, the first one received will have prior right of acceptance. If two or more such bids are received in the same day, the first one opened will be entitled to acceptance.

(5) No bids will be considered on less than 20 trees of a variety, except, that if a bid is made for 100 trees or more, for one kind of fruit, as for example apples, the bidder may select his 100 apple trees in such numbers of each as he desires, but only from the 9 kinds here offered. If his bid is for 100 pears, he may bid 90 Bartlett, 5 Seckel and 5 Kieffer; no bid, however, will be considered such as, for example, 15 Baldwin, 15 Spy, 15 Greening, 15 Bartlett, 15 German Prune, 15 Montmorency and 10 Elberta, whereas the same kind of a bid for 20 of each variety would be accepted.

(6) The trees offered below are not the same grades as those offered by the bundle, but are the extra size standard trees offered in our catalogue-the highest grade, and every tree selected with the greatest care.

(7) We would suggest that you use the order blank in making your bids, and if not accepted we will return same to you.

The closest estimate we can make at this date warrants us in offering only the following list; it may be that later, in our April Bulletin, we will find we have other varieties that we may be able to offer, or possibly more of some of these same varieties.

STANDARD APPLE TREES, Extra Size, 5-7 ft. Listed in Catalogue $\$ 20.00$ per 100

500 Baldwin

75 King

200 McIntosh
250 Northern Spy

300 R. I. Greening

100 Rome Beauty
200 Stark

100 Stayman

100 Winter Banana

STANDARD PEAR TREES, Extra Size, 5-7 ft. Listed in Catalogue $\$ 25.00$ per 100 400 Bartlett 50 Clapp Favorite

100 Kieffer

STANDARD PLUM TREES, Extra Size, 5-7 ft. Listed in Catalogue $\$ 30.00$ per 100 200 Burbank 150 Fellemberg 150 German Prune 100 Shropshire Damson

STANDARD CHERRY TREES, Extra Size, 5-7 ft. Listed in Catalogue $\$ 30.00$ per 100 150 Montmorency

STANDARD PEACH TREES, Extra Size, about 4-5 ft. Listed in Catalogue $\$ 12.00$ per 100 200 Champion 100 Crawford Early 400 Elberta 200 Carman 